\title{
PENGELOLAAN ASET DAERAH BERBENTUK BANGUNAN DI KOTA PARIAMAN DALAM RANGKA TERTIB ADMINISTRASI
}

\section{FAUZAN ZAKIR}

\author{
Sekolah Tinggi Ilmu Hukum Padang
}

\begin{abstract}
The purpose of this paper is to examine the management of building assets in the City of Pariaman in the context of administration. The research used is naormative juridical. The implementation of the work on the management of regional goods which is charged is not optimal, as well as inadequate funding to carry out the management of regional property, so that activities to support the orderly implementation of the management of regional goods do not run effectively as well as funding for procurement of goods which must be in accordance with the facilities and infrastructure which should be used to cover work desks, work chairs, etc., does not yet meet the standards for facilities and infrastructure determined by the City of Pariaman Regulations. There must be firmness and clarity carried out by DPPKA in reporting goods to each SKPD so that reporting of the use of goods is timely
\end{abstract}

Keywords: Management, Regional Assets, Buildings, Pariaman, Orderly Administration.

Abstrak: Tujuan penulisan ini adalah meneliti tentang pengelolaan asset daerah berbenruk bangunan di Kota Pariaman dalam rangka tertin administrasi. Penelitian yang digunakan adalah yuridis naormatif. Pelaksanaan pekerjaan pengelolaan barang daerah yang dibebankan menjadi tidak maksimal, serta pendanaan yang kurang memadai untuk melaksanakan kegiatan pengelolaan barang milik daerah, sehingga kegiatan untuk mendukung tertibnya pelaksanaan pengelolaan barang daerah tidak berjalan dengan efektif seperti halnya pendanaan terhadap pengadaan barang yang harus sesuai dengan sarana dan prasarana yang seharusnya digunakan melipuiti meja kerja, kursi kerja dan lain sebagainya belum memenuhi standar sarana dan prasaran yang ditentukan melalui Peraturan Kota Pariaman. Harus ada ketegasan dan kejelasan yang dilaksanakan oleh DPPKA dalam pelaporan barang kepada setiap SKPD sehingga pelaporan penggunaan barang tepat pada waktunya

Kata Kunci: Pengelolaan, Aset Daerah, Bangunan, Pariaman, Tertib Adminsitrasi.

\section{A. Pendahuluan}

Perubahan paradigma baru pengelolaan barang milik negara / aset negara yang ditandai dengan dikeluarkannya Peraturan Pemerintah No. 6 tahun 2006 yang merupakan peraturan turunan Undang-Undang No. 1 tahun 2004 tentang Perbendaharaan Negara, telah memunculkan optimisme baru best practices dalam penataan dan pengelolaan aset negara yang lebih tertib, akuntabel, dan transparan kedepannya. Pengelolaan aset negara yang professional dan modern dengan mengedepankan good governance di satu sisi diharapkan akan mampu meningkatkan kepercayaan pengelolaan keuangan negara dari masyarakat /stake-holder. Pengelolaan aset negara dalam pengertian yang dimaksud dalam Pasall Ayat (1) dan Ayat (2) Peraturan Pemeintah No.6 tahun 2006 adalah tidak sekedar administratif semata, tetapi lebih maju berfikir dalam menangani aset negara, dengan bagaimana meningkatkan efisiensi, efektifitas dan menciptakan nilai tambah dalam mengelola aset. Oleh karena itu, lingkup pengelolaan aset Negara mencakup perencanaan kebutuhan dan 
penganggaran; pengadaan; penggunaan; pemanfaatan; pengamanan dan pemeliharaan; penilaian; penghapusan; pemindahtanganan; penatausahaan; pembinaan, pengawasan, dan pengendalian. Proses tersebut merupakan siklus logistik yang lebih terinci yang didasarkan pada pertimbangan perlunya penyesuaian terhadap siklus perbendaharaan dalam konteks yang lebih luas (keuangan negara).

Dalam pelaksanaan otonomi daerah, pemerintah daerah dalam implementasi kebijakan pengelolaan barang milik daerah merupakan komponen penting dalam penyelenggaraan kegiatan pengelolaan keuangan daerah. Oleh karena itu pengelola barang milik daerah perlu melakukan pengorganisasian dengan baik. Salah satu peraturan yang menjadi dasar terhadap pengelolaan barang milik daerah Kabupaten Sintang adalah disamping UU No. 6 Tahun 2006 tentang Pengelolaan Barang Milik Negara/Daerah, Peraturan Menteri Keuangan No. 120/PMK.06/2007 tentang Penatausahaan Barang Milik Negara, dan Peraturan Menteri Keuangan Nomor: 96/PMK.06/2007 tentang Tata Cara Pelaksanaan Penggunaan, Pemanfaatan, Penghapusan, dan Pemindahtanganan Barang Milik Negara, juga berdasarkan Peraturan Pemerintah No. 6 tahun 2006.

Dinas Pendapatan, Pengelolaan Keuangan dan Aset Kabupaten Sintang dalam hal ini Bidang Aset sebagai pembantu pengelola Barang Daerah yang mengkoordinir penyelenggaraan pengelolaan barang milik daerah di lingkungan SKPD Pemerintah Kota Pariaman masih ditemui ada beberapa SKPD jarang melaporkan administrasi barang. Berdasarkan pengamatan dari surat-surat yang masuk ke DPPKA Kabupaten Pariaman khususnya Bidang Aset berkaitan dengan kewajiban SKPD yang memberikan laporan administrasi barang daerah, masih ada ditemui beberapa SKPD yang belum menyampaikan laporan administrasi barang daerah. Sehubungan dengan hal itu maka SKPD dalam pelaksanaan kegiatan pengelolaan barang milik daerah masih banyak ditemui permasalahan sebagai berikut (Nyemas Hasfi, Martoyo dan Dwi Haryono, 2013): 1) Barang-barang yang rusak yang dibiarkan begitu saja; 2) Pengadaan barang tidak sesuai RKBMD; 3) Pembelian barang yang tidak sesuai dengan standarisasi; 4) Aset yang masih belum ada pengamanannya; 5) Pembelian barang yang tidak tercatat dalam buku inventaris; 6) Kehilangan barang yang tidak ada administrasi pelaporannya; 7) Pembiayaan untuk pengelolaan barang daerah masih minim; 8) Rendahnya kinerja pengurus dan pembantu pengurus barang; 9) lemahnya sanksi dalam pelaporan barang; 10) Balik nama bangunan daerah yang belum jelas; 11) Permasalahan ganti rugi kepada masyarakat yang belum selesai; dan 12) Hak ulayat yang belum jelas kedudukannnya di dalam memberikan wakaf kepada pemerintahan kota Pariaman.

Pengelolaan barang milik daerah pada dasarnya berhubungan dengan menajemen materi dan manajemen perlengkapan daerah. Manajemen materi menurut Serdamayanti (2000:169) adalah proses kegiatan perencanaan kebutuhan pemilihan sumber, pembelian, pemindahan, penyimpanan dan pengawasan materil/produksi dalam rangka meningkatkan keuntungan perusahaan. Menurut Syamsi (1983:9) yang dimaksud dengan perlengkapan daerah adalah perlengkapan materil atau milik Pemerintah Daerah, sedangkan menajemen perlengkapan daerah atau pengelolaan perlengkapan daerah adalah segenap proses penyelenggaraan yang meliputi fungsi merencanakan, mengatur melaksanakan dan mengontrol terhadap barang-barang milik Pemerintah Daerah, sehingga tercapailah efisiensi di bidang perlengkapan daerah. Keppres Nomor 80 Tahun 2003 tentang pedoman pelaksanaan pengadaan barang/jasa 
Instansi Pemerintah, barang adalah benda dalam berbagai bentuk dan uraian, yang meliputi bahan baku, barang setengah jadi, peralatan, yang spesifikasinya ditetapkan oleh pengguna barang jasa. Berdasarkan lampiran Permendagri Nomor 17 Tahun 2007 tentang petunjuk teknis pelaksanaan pengelolaan barang daerah dijelaskan bahwa: "Barang Daerah adalah semua kekayaan daerah baik yang dimiliki maupun yang dikuasai yang berwujud, baik yang bergerak maupaun tidak bergerak serta bagianbagiannya ataupun yang merupakan satuan tertentu yang dapat dinilai, dihitung, diukur, atau ditimbang termasuk hewan dan tumbuh- tumbuhan kecuali uang dan surat berharga lainnya". Lebih jauh disebutkan barang milik daerah terdiri dari: a) Barang yang dimiliki oleh pemerintah daerah; b) Barang yang dimiliki oleh perusahaan daerah atau Badan Usaha Milik Daerah (Nyemas Hasfi, Martoyo dan Dwi Haryono, 2013).

Berdasarkan Lampiran Permendagri Nomor 17 Tahun 2007 tentang petunjuk teknis pelaksanaan pengelolaan barang daerah, maka barang daerah dikelompokkan kedalam 19 bidang, yaitu : Bidang Tanah, Bidang jalan dan jembatan, Bidang bagunaan air, Bidang instalasi, Bidang Jaringan, Bidang bangunan gedung, Bidang monumen, Bidang alat-alat besar, Bidang alat-alat angkut, Bidang alat bengkel, Bidang alat-alat pertanian, Bidang alat-alat kantor dan rumah tangga, Bidang alat studio, Bidang alat kedokteran, Bidang alat laboraturium, Bidang buku/perpustakaan, Bidang barang bercorak kesenian, kebudayaan, Bidang hewan/ternak dan tumbuh-tumbuhan, Bidang alat keamanan. Selanjutnya disebutkan juga dalam Peraturan Menteri Dalam Negeri Nomor 17 Tahun 2007 tentang pedoman pengelolaan barang daerah, bahwa yang dimaksud dengan barang inventaris adalah "seluruh barang yang dimiliki/dikuasai oleh pemerintah daerah yang penggunaannya lebih dari satu tahun dan dicatat serta didaftarkan dalam buku inventaris".

Pengelolaan barang milik negara/daerah sebagaimana diatur dalam peraturan pemerintah ini dilaksanakan dengan memperhatikan asas-asas sebagai berikut (Suwondo, 2009): 1) Azas fungsional; 2) Azas kepastian hukum; 3) Azas transparansi; 4) Azas efisiensi; 5) Azas akuntabilitas; dan 6) Azas kepastian nilai. Barang milik negara/daerah meliputi barang yang dibeli atau diperoleh atas beban APBN/APBD dan juga barang yang berasal dari perolehan lainnya yang sah. Adapun barang yang berasal dari perolehan lain yang sah meliputi: 1) Barang yang diperoleh dari hibah/sumbangan atau yang sejenis; 2) Barang yang diperoleh sebagai pelaksanaan dari perjanjian/kontrak; 3) Barang yang diperoleh berdasarkan ketentuan undang-undang; dan 4) Barang yang diperoleh berdasarkan putusan pengadilan yang telah memperoleh kekuatan hukum tetap. Pengelolaan barang milik negara/daerah berdasarkan PP Nomor 6 Tahun 2006 meliputi: 1) Perencanaan kebutuhan dan penaganggaran; 2) Pengadaan; 3) Penggunaan; 4) Pemanfaatan; 5) Pengamanan dan pemeliharaan; 6) Penilaian; 7) Penghapusan; 8) Pemindah tanganan; 9) Penatausahaan; dan 10) Pembinaan, pengawasan dan pengendalian.

Untuk mendukung pengelolaan aset daerah secara efisien dan efektif serta menciptakan transparansi kebijakan pengelolaan aset daerah, maka pemerintah daerah perlu memiliki atau mengembangkan sistem informasi menajemen yang komprehensif dan handal sebagai alat untuk menghasilkan laporan pertanggungjawaban. Selain itu, sistem informasi tersebut juga bermanfaat untuk dasar pengambilan keputusan mengenai kebutuhan barang dan estimasi kebutuhan belanja pembangunan (modal) dalam penyusunan APBD, dan untuk memperoleh informasi manajemen aset daerah yang memadai maka diperlukan dasar pengeolaan kekayan aset yang memadai juga, dimana menurut Mardiasmo (2002:87) terdapat tiga prinsip dasar pengelolaan 
kekayaan aset daerah yakni (Suwondo, 2009): (1) adanya perencanaan yang tepat, (2) pelaksanaan/pemanfaatan secara efisien dan efektif, dan (3) pengawasan (monitoring).

Pemerintah daerah perlu membuat perencanaan kebutuhan aset yang akan digunakan/dimiliki. Berdasarkan rencana tersebut, pemerintah daerah kemudian mengusulkan anggaran pengadaannya. Dalam hal ini, masyarakat dan DPRD perlu melakukan pengawasan (monitoring) mengenai apakah aset atau kekayaan untuk dimiliki daerah tersebut benar-benar dibutuhkan daerah. Seandainya memang dibutuhkan, maka pengadaannya harus dikaitkan dengan cakupan layanan yang dibutuhkan dan diawasi apakah ada mark-up dalam pembelian tersebut. Setiap pembelian barang atau aset baru harus dicatat dan terdokumentasi dengan baik dalam sistem database kekayaaan daerah.

Menurut Mardiasmo (2002), pada dasarnya kekayaan daerah dapat diklasifikasikan menjadi dua jenis yaitu: 1) Kekayaan yang sudah ada (eksis) sejak adanya daerah tersebut. Kekayaan jenis ini meliputi seluruh kekayaan alam dan geografis kewilayahannya. Contohnya adalah tanah, hutan, tambang, gunung, danau, pantai dan laut; dan 2) Kekayaan yang akan dimiliki baik yang berasal dari aktivitas pemerintah daerah yang didanai APBD serta kegiatan perekonomian daerah lainnya. Contohnya adalah jalan, jembatan, kendaraan, dan barang modal lainnya.

Kekayaan milik daerah harus dikelola secara optimal dengan memperhatikan prinsip efisiensi, efektifitas, transparansi, dan akuntabilitas publik. Masyarakat dan DPRD yang harus melakukan pengawasan (monitoring) terhadap pemanfaatan aset daerah tersebut agar tidak terjadi penyalahgunaan kekayaan milik daerah. Hal yang cukup penting diperhatikan pemerintah daerah adalah perlunya dilakukan perencanaan terhadap biaya operasional dan pemeliharaan untuk setiap kekayaan yang dibeli atau diadakan. Hal ini disebabkan sering kali biaya operasi dan pemeliharaan tidak dikaitkan dengan belanja investasi/modal. Mestinya terdapat keterkaitan antara belanja investasi/modal dengan biaya operasi dan pemeliharaan yang biaya tersebut merupakan commitment cost yang harus dilakukan. Selain biaya operasi dan pemeliharaan, biaya lain yang harus diperhatikan misalnya biaya asuransi kerugian. Pengelolaan kekayaan daerah harus memenuhi prinsip akuntabilitas publik.

Pemerintah Kota Pariaman, Sumatera Barat, menyosialisasikan pedoman pengelolaan barang milik daerah kepada Organisasi Perangkat Daerah (OPD) guna memaksimalkan penilaian opini dari Badan Pemeriksa Keuangan (BPK). Laporan aset dan barang milik daerah merupakan indikator terbesar dalam penerimaan opini sehingga tiap pejabat daerah harus memahami agar sesuai aturan. Hal itu disampaikan pada sosialisasi Peraturan Menteri Dalam Negeri (Permendagri) nomor 19 tahun 2016, tentang pedoman pengelolaan barang milik daerah, dan sosialisasi perubahan aplikasi barang milik daerah (BMD). Sosialisasi yang dilakukan bertujuan untuk menciptakan penatakelolaan pemerintahan yang baik bagi masyarakat. Hal ini sangat dibutuhkan, apalagi pengelolaan aset dan barang milik daerah memiliki andil besar dalam neraca keuangan daerah serta Laporan Kinerja Pemerintahan Daerah (LKPD) (Mukhlis Ruhman, 2020).

Selain itu walaupun saat ini terdapat aplikasi khusus yang dikeluarkan oleh Kementerian untuk melaporkan aset dan barang milik daerah, pejabat setempat tetap tidak boleh lengah dan ceroboh sebab hal itu hanya merupakan alat bantu. Teknologi itu hanya alat bantu, sedangkan laporan yang dibuat harus sesuai dengan aturan dan dapat dipertanggungjawabkan sehingga harus maksimal dalam pemahaman dan 
pengelolaannya. Atas hal tersebut maka tulisan ini akan membahas: 1) profil wilayah kota Pariaman; dan 2) pengelolaan asset daerah berbentuk bangunan di kota pariaman

\section{B. Metodologi Penelitian}

Untuk melakukan penelitian ini dan untuk melengkapi bahan-bahan atau data yang konkrit, jawaban yang objektif dan ilmiah serta dapat dipertanggung jawabkan kebenarannya. Penelitian ini merupakan penelitian deskriptif analitis yang menggambarkan tentang pengelolaan asset daerah berbentuk bangunan di kota pariaman. Pendekatan yang digunakan dalam penelitian ini adalah pendekatan yuridis normatif, digunakan untuk mengetahui tentang pelaksanaan pengelolaan asset daerah berbentuk bangunan di kota pariaman.

\section{Hasil dan Pembagasa}

\section{Profil Wilayah Kota Pariaman Berdasarkan Undang-Undang Nomor 12 Tahun 2002 Tentang Pembentukan Kota Pariaman}

Berdasarkan Undang-Undang No. 12 Tahun 2002 tentang Pembentukan Kota Pariaman sebagai salah satu Kota yang berada dalam wilayah Propinsi Sumatera Barat mempunyai luas wilayah sebesar 73,36 Km2 dan luas lautan 282,56 km2, dengan panjang garis pantai $12,00 \mathrm{Km} 2$ yang mencakup 3 (tiga) Kecamatan yaitu Kecamatan Pariaman Utara, Kecamatan Pariaman Tengah dan Kecamatan Pariaman Selatan. Dan kemudian berdasarkan Peraturan Daerah Kota Pariaman No. 10 Tahun 2009, kecamatan di Kota Pariaman telah bertambah menjadi 4 (empat) kecamatan yakni: Kecamatan Pariaman Utara, Kecamatan Pariaman Tengah, Kecamatan Pariaman Selatan dan Kecamatan Pariaman Timur. Kota Pariaman secara administrasi berbatasan langsung dengan daerah sebagai berikut (PPID Kota Pariman, 2020): 1) Sebelah Utara: Kecamatan V Koto Kp. Dalam dan V Koto Timur (Kab. Padang Pariaman); 2) Sebelah Selatan: Kecamatan Nan Sabaris (Kab. Pd. Pariaman); 3) Sebelah timur: Kecamatan VII Koto Sungai Sarik (Kab. Padang Pariaman); dan 4) Sebelah Barat: Samudra Indonesia.

Kota Pariaman secara geografis terletak pada $0^{\circ} 33^{\prime} 00^{\prime \prime}-0^{\circ} 40^{\prime} 43^{\prime \prime}$ Lintang Selatan dan $100^{\circ} 10^{\prime} 33^{\prime}$ ' - $100^{\circ} 10^{\prime} 55^{\prime \prime}$ Bujur Timur. Kota Pariaman terbentang pada jalur strategis lintas Sumatera Bagian Barat yang menghubungkan Propinsi Sumatera Utara dan Propinsi Sumatera Barat. Letak geografis Kota Pariaman di daerah perlintasan antara beberapa kota di Sumatera Barat khususnya dan regional umumnya merupakan faktor strategis bagi kota ini. Kota Pariaman juga memiliki kawasan pesisir yang terbentang dengan potensi perikanan dan pariwisata yang tinggi. Dengan berkembangnya kegiatan perdagangan dan pariwisata, maka posisi Kota Pariaman sebagai pusat perdagangan hasil pertanian dan pariwisata pantai akan menjadi semakin penting (Wikipedia, 2020).

Kota Pariaman merupakan hamparan dataran rendah yang terletak di pantai barat Propinsi Sumatera Barat dengan ketinggian antara 2 sampai dengan 35 meter di atas permukaan laut dengan sedikit daerah perbukitan. Dan memiliki 6 buah pulau-pulau kecil: Pulau Bando, Pulau Gosong, Pulau Ujung, Pulau Tangah, Pulau Angso dan Pulau Kasiak. Panjang pantai lebih kurang 12,7 kilometer. Keadaan topografi wilayah, geomorfologi dan bentuk wilayah secara bersama-sama membentuk pola aliran sungai. Kota Pariaman dilalui oleh tiga buah sungai yaitu Batang Manggung yang melalui Kecamatan Pariaman Utara, Batang Piaman yang melewati Kecamatan Pariaman Tengah dan Batang Mangau yang melalui Pariaman Selatan. 
Secara teoritis, struktur internal Kota Pariaman dikembangkan dengan konsep pengembangan Kota Pariaman sebagai Kota Pariwisata dan sebagai Kota Perdagangan dan Jasa. Konsep pengembangan tersebut didukung dengan pengembangan wilayah terbangun yang mempunyai potensi lahan lebih luas untuk kegiatan terbangun yang lebih intensif. Struktur ruang Kota Pariaman dibentuk oleh jaringan dan komponen ruang. Jaringan yang dominan membentuk struktur ruang adalah jaringan jalan. Kriteria perencanaan struktur jalan yang diterapkan adalah dengan memanfaatkan jalan arteri provinsi sebagai "keran" aliran pergerakan dan pemicu kegiatan-kegiatan ekonomi bagi penduduk Kota Pariaman pada umumnya.

Berdasarkan potensi dan permasalahan yang dihadapi dalam upaya pengembangan Kota Pariaman, maka dirumuskan konsep pengembangan struktur ruang kota yang dasar pemikirannya terutama dengan mempertimbangkan hal-hal sebagai berikut: 1) Dapat meminimalisasi dampak kerusakan yang ditimbulkan oleh terjadinya bencana gempa bumi dan tsunami; 2) Mengoptimalkan sistem jaringan jalan dan pola ruang yang sudah ada dan sudah terbentuk; 3) Mengoptimalkan sumberdaya yang ada; dan 4) Menyiapkan Kota Pariaman sebagai bagian dari pengembangan Kawasan Metropolitan Padang Dan Sekitarnya.

\section{Pengelolaan Aset Daerah Berbentuk Bangunan Di Kota Pariaman}

Proses pengelolaan barang milik daerah di DPPKA Kota Pariaman melalui beberapa tahapan yang mengacu pada PP No.6 Tahun 2006, Permendagri No.17 Tahun 2007, dimana tahapan proses pengelolaan barang milik daerah meliputi:1) perencanaan kebutuhan dan penganggaran, 2) pengadaan, 3) penerimaan dan penyaluran, 4) penggunaan, 5) penatausahaan, 6) pengamanan dan pemeliharaan, 7) pemanfaatan, 8) penilaian, dan 9) penghapusan barang milik daerah (Pemerintah Kota Pariaman, 2015).

Perencanaan Kebutuhan dan Penganggaran, salah satu proses pengelolaan barang milik daerah yang dilakukan oleh Pemerintah Daerah Kota Pariaman dalam tahapan perencanaan kebutuhan dan penganggaran dilakukan dengan melihat standar kebutuhan meliputi standar jenis, macam, jumlah dan besarnya barang milik daerah yang dibutuhkan, juga merupakan standarisasi sarana dan prasarana kerja Pemerintah Daerah melalui pembakuan ruang kantor, perlengkapan kantor, rumah dinas dan kendaraan dinas. Standarisasi ini tentunya juga berpedoman pada Permendagri No.7 tahun 2006 tentang Standarisasi Sarana dan Prasarana Kerja Pemda. Kemudian standar harga merupakan pembakuan harga barang milik daerah sesuai jenis, spesifikasi dan kualitas dalam satu periode tertentu biasanya 1 (satu) tahun dan ditetapkan oleh Kepala Daerah (Pemerintah Kota Pariaman, 2015).

Pengadaan Barang Milik Daerah. Kota Pariaman menggunakan penyedia barang dan jasa, dilakukan dengan pelelangan umum atau seleksi umum kecuali dalam rangka efisiensi atau dalam kondisi tertentu atau barang/jasa bersifat khusus, dilaksanakan dengan metode lainnya seperti pelelangan terbatas (seleksi terbatas), pemilihan langsung (seleksi langsung) dan penunjukkan langsung. Swakelola, swakelola adalah pekerjaan yang direncanakan, dikerjakan, dan diawasi sendiri oleh pelaksana swakelola dengan menggunakan tenaga sendiri atau tenaga dari luar baik tenaga ahli maupun tenaga upah borongan. Dalam pengadaan barang dan jasa milik daerah ini Kepala SKPD bertanggungjawab baik tertib administrasi maupun kualitas barang serta melaporkan pelaksanaannya kepada Kepala Daerah melalui pengelola yang dilengkapi dokumen pengadaan barang/jasa (Pemerintah Kota Pariaman, 2015). 
Penerimaan dan Penyaluran. Proses penerimaan yang dilakukan pada masingmasing SKPD Kabupaten Sintang adalah dimulai dari perlakuan tehadap setiap pengadaan barang inventaris dilakukan melalui tiga pintu yaitu pada Sub Bagian Perlengkapan, selanjutnya Sub Bagian Perlengkapan menyalurkannya ke setiap bagian/bidang dan Sub Bagian/Seksi/Bidang. Sedangkan terhadap pengadaan barang pakai habis dilakukan oleh masing-masing Pejabat Pelaksana Teknis Kegiatan (PPTK), dimana setiap barang yang dibeli langsung diterima oleh PPTK karena belum tersedianya gudang di masing-masing SKPD. Penerimaan barang milik daerah Pemerintah Kabupaten Sintang adalah sebagai tindak lanjut dari hasil pengadaan dari pihak ketiga berdasarkan perjanjian dan pelaksanaan dari suatu perijinan tertentu yang dilengkapi dengan dokumen pengadaan dan berita acara. Semua barang bergerak penerimaannya dilakukan oleh penyimpan barang/pengurus barang, untuk itu penerimaan barang oleh penyimpan barang/pengurus barang dilaksanakan di gudang penyimpanan. Selain itu Pemerintah Daerah dapat menerima barang dari pihak ketiga yang merupakan sumbangan, hibah, wakaf dan penyerahan dari masyarakat. Penyerahan dari Pihak Ketiga, dituangkan dalam Berita Acara (Pemerintah Kota Pariaman, 2015).

Penggunaan, diketahui bahwa, penggunaan barang milik daerah sudah berjalan dengan efektif. Pengguna yang tidak menyerahkan tanah atau bangunan yang tidak digunakan untuk menyelenggarakan tugas pokok dan fungsi SKPD bersangkutan kepada Kepala Daerah dikenakan sanksi berupa pembekuan dana pemeliharaan tanah atau bangunan dimaksud. Tanah atau bangunan yang tidak digunakan sesuai tugas pokok dan fungsi SKPD, dicabut penetapan status penggunaannya dan dapat dialihkan kepada SKPD lainnya. Kasus yang sering terjadi terhadap penggunaan barang milik daerah adalah adanya perpindahan dari pengguna barang dikarenakan adanya mutasi antar SKPD sehingga sering ditemui apalagi seperti barang milik daerah seperti laptop jarang dilakukan proses pengembalian atas hak penggunaannya. Sehingga menyulitkan dalam proses pembuatan laporannya karena fisik sudah tidak ada. Dalam proses penggunaan barang milik daerah sudah efektif, penggunaan barang bergerak di DPPKA tidak mengalami hambatan karena penggunaan kendaraan roda empat dan roda dua beserta laptop tercatat oleh Sub Bidang Perlengkapan SKPD. Hanya saja penggunaan barang belum digunakan dengan baik sebagai pendukung tugas pokok dan fungsi pada masing-masing SKPD (Pemerintah Kota Pariaman, 2015).

Penatausahaan.Penatausahaan dan penghapusan barang milik daerah yang dilaksanakan oleh Dinas Pendapatan, Pengelolaan Keuangan dan Aset Kabupaten Sintang sudah sesuai dengan ketentuan yang berlaku. Kegiatan pembukuan Pengguna/Kuasa Pengguna melakukan pendaftaran dan pencatatan barang milik daerah ke dalam Daftar Barang Pengguna (DBP)/Daftar Barang Kuasa Pengguna (DBKP) menurut penggolongan dan kodefikasi barang (Pemerintah Kota Pariaman, 2015).

Pengamanan dan Pemeliharaan, Proses pengamanan dan pemeliharaan yang dilaksanakan oleh masing-masing SKPD belum terlaksana dengan baik. Proses pengamanan sebagaimana yang dijelaskan oleh Kepala Bidang Aset dilaksanakan dimulai dari pencatatan oleh pengguna dan dilaporkan kepada pengelola melalui pembantu pengelola, pemasangan label dilakukan oleh pengguna berkoordinasi dengan pembantu pengelola kemudian pembantu pengelola dan/atau SKPD menyelesaikan bukti kepemilikan barang milik daerah. Dalam hal pengamanan yang dilakukan belum bisa maksimal seperti halnya pematokan terhadap batas tanah masih ada belum dilaksanakan sehingga diperlukan sistem dan prosedur yang dilakukan untuk E-ISSN: 2657-0300 Lembaga Penelitian dan Penerbitan Hasil Penelitian Ensiklopedia 15 
menunjang kegiatan ini agar pengamanan yang dilaksanakan terhadap barang milik daerah dapat berjalan dengan tertib (Pemerintah Kota Pariaman, 2015).

Pemanfaatan, Pemanfaatan merupakan pendayagunaan barang milik daerah yang tidak dipergunakan sesuai tugas pokok dan fungsi SKPD dalam bentuk pinjam pakai, sewa, kerja sama pemanfaatan, bangun guna serah, bangun serah guna dengan tidak merubah status kepemilikan. Pemanfaatan barang milik daerah berupa tanah atau bangunan dilaksanakan oleh pengelola setelah mendapat persetujuan Kepala Daerah, selain tanah atau bangunan dilaksanakan oleh pengguna setelah mendapat persetujuan pengelola. Kegiatan pemanfaatan barang terdiri dari: Pinjam Pakai, Sewa, Kerjasama pemanfaatan dan Bangun Guna Serah (Pemerintah Kota Pariaman, 2015).

Penilaian Barang Daerah, Diketahui bahwa, kegiatan penilaian barang daerah tidak sepenuhnya dilaksanakan oleh Dinas Pendapatan, Pengelolaan Keuangan dan Aset Kabupaten Sintang sebagai unit kerja teknis yang membantu pengelolaan barang serta mengkoordinir dan membina SKPD. Namun penilaian yang umumnya sering dilakukan adalah yang berkaitan dengan penghapusan barang dengan tujuan untuk pernbongkaran bangunan kantor milik Pemerintah Kota Pariaman yang sudah rusak atau tidak layak untuk dipergunakan (Pemerintah Kota Pariaman, 2015).

Penghapusan. Pola penghapusan barang milik daerah dimulai dari menerbitkan Surat Keputusan dari pejabat yang berwenang untuk membebaskan pengguna atau kuasa pengguna dan/atau pengelola dari tanggungjawab administrasi dan fisik atas barang yang berada dalam penguasaannya (Pemerintah Kota Pariaman, 2015), kemudian penghapusan dari daftar barang pengguna/kuasa pengguna, penghapusan dari daftar barang milik daerah pada pengelola serta penghapusan pemusnahan bagi barang yang tidak dapat digunakan/dimanfaatkan dan tidak dapat dipindahtangankan atau alasan lain sesuai ketentuan perundang-undangan yang berlaku.

\section{Penutup}

Pelaksanaan pekerjaan pengelolaan barang daerah yang dibebankan menjadi tidak maksimal, serta pendanaan yang kurang memadai untuk melaksanakan kegiatan pengelolaan barang milik daerah, sehingga kegiatan untuk mendukung tertibnya pelaksanaan pengelolaan barang daerah tidak berjalan dengan efektif seperti halnya pendanaan terhadap pengadaan barang yang harus sesuai dengan sarana dan prasarana yang seharusnya digunakan melipuiti meja kerja, kursi kerja dan lain sebagainya belum memenuhi standar sarana dan prasaran yang ditentukan melalui Peraturan Kota Pariaman. Harus ada ketegasan dan kejelasan yang dilaksanakan oleh DPPKA dalam pelaporan barang kepada setiap SKPD sehingga pelaporan penggunaan barang tepat pada waktunya

\section{Daftar Pustaka}

Mukhlis Ruhman, Pariaman Sosialisasikan Pedoman Pengelolaan Barang Milik Daerah, http://www.antarasumbar.com/berita/203620/pariaman-sosialisasikanpedoman-pengelolaan-barang-milik-daerah.html, diakses pada tanggal 15 Januari 2020.

Nyemas Hasfi, Martoyo dan Dwi Haryono, 2013, Pengelolaan Barang Milik Daerah, Jakarta, Universitas Tarumanegara.

Pemerintah Kota Pariaman, 2015, Evaluasi Pelaksanaan RKPD Tahun 2015, Pariman, Pemerintahan Kota Pariaman. 
PPID Kota Pariman, Dinas Pendapatan dan Pengelolaan Keuangan Aset Daerah, http://ppid.pariamankota.go.id/wp-content/uploads/2016/08/DPPKA.pdf, diakses pada tanggal 15 September 2015.

Suwondo, 2009, Desentralisasi Pelayanan Publik: Hubungan Komplementer Antara Sektor Negara, Mekanisme PasarDan Organisasi Non-Pemerintah, Yogjakarta, PSKK UGM.

Wikipedia, Sejarah Kota Pariaman, https://id.wikipedia.org/wiki/Kota_Pariaman, diakses pada tanggal 15 Januari 2020. 